\title{
CAN MEAN PLATELET VOLUME INDICATE HELICOBACTER POSITIVITY AND SEVERITY OF GASTRIC INFLAMMATION? AN ORIGINAL STUDY AND REVIEW OF THE LITERATURE
}

\begin{abstract}
Tarik Akar
Bülent Ecevıt Unıversity Medical Faculty, Department of Gastroenterology, Zonguldak, Turkey

SUMMARY - Helicobacter pylori $(H$. pylori) is a common problem and a significant cause of chronic gastric inflammation. H. pylori, ongoing gastric inflammation and its severity are the most critical component of precursors of gastric cancer. Hypothetically, every chronic tissue injury activates platelets, and the mean platelet volume (MPV) reflects this action well. The potential relationship between $H$. pylori and platelet count has been shown before. However, there are few and conflicting papers about the relationship between MPV and $H$. pylori related chronic gastric inflammation and its severity. The study aimed to assess any potential relationship between MPV and presence of $\mathrm{H}$. pylori, as well as the severity of chronic gastric inflammation. A total of 6890 endoscopic reports were initially evaluated, and a total of 218 dyspeptic patients having undergone upper endoscopy were included. Of these, 118 (54.2\%) were $H$. pylori positive and 100 (45.8\%) were H.pylori negative. At least four gastric biopsies were obtained and evaluated according to Sydney classification. Age, gender, hemoglobin, mean corpuscular volume, ferritin, serum iron and C-reactive protein, as well as endoscopic findings were also recorded. A $p<0.05$ was accepted as significant. The MPV and platelet count did not differ between $H$. pylori positive and $H$. pylori negative groups of patients $(\mathrm{p}>0.05)$. There were no differences and correlation between MPV and gastric inflammation severity according to Sydney classification ( $p>0.05$ ). When stratifying MPV as $<9.15 \mathrm{fL}$ and $>9.15 \mathrm{fL}$, there was no difference between $H$. pylori positive and $H$. pylori negative groups either ( $>>0.05)$. In this study, we found no relationship between MPV and presence of $H$. pylori or severity of gastric inflammation. Although there are still conflicting publications on this issue, in our opinion and according to the results of this study, MPV is not a suitable marker for evaluation of gastric inflammation severity, being $H$. pylori either positive or negative.
\end{abstract}

Key words: Mean platelet volume; Helicobacter pylori; Gastritis; Inflammation

\section{Introduction}

Helicobacter pylori (H. pylori) infection and related clinical conditions such as chronic gastric inflammation, gastric cancer, and immune thrombocytopenia are still growing clinical problems all over the world be-

Correspondence to: Assoc. Prof. Tarık Akar, PhD, Tersane sitesi A2 blok D:6, Zonguldak, Turkey

E-mail: drtarikakar@gmail.com

Received July 19, 2018, accepted September 12, 2018 cause of some well-known difficulties in their treatment, diagnosis, and management ${ }^{1-4}$. Moreover, it may not be possible to be recognized by patient or clinicians unless presented with a noisy clinical picture as peptic ulcer bleeding because it often leads to slow chronic infection without manifesting itself ${ }^{5}$. It is possible to diagnose $H$. pylori infection by noninvasive tests, as recommended by well-known guidelines ${ }^{6}$. However, the degree of chronic gastric inflammation that is commonly evaluated by Sydney classification and the con- 
ditions that increase susceptibility to stomach cancer can almost only be understood by upper endoscopic biopsies, not yet with noninvasive tests ${ }^{6}$. Nevertheless, even nowadays, the possibility of upper endoscopy is still not available everywhere and is not suitable for every patient, while histologic examinations of endoscopic biopsies are expensive and time-consuming ${ }^{7}$. Consequently, a new, simple, reliable and straightforward indicator of chronic inflammation of the stomach such as a blood marker is needed to overcome such difficulties ${ }^{8}$.

It is well-known that acute or chronic inflammation occurring in any part of human tissues activates platelets via some specific cytokines, chemokines and immune mediators stimulated by various cells ${ }^{8}$. The mean platelet volume (MPV) is a part unit of complete blood count analysis that represents mainly platelet induction and aggravation, and that can easily be obtained in daily routine. It has recently been studied as an inflammatory marker, a disease severity index and a predictor of prognosis in a variety of acquired diseases including localized psoriasis, rheumatoid arthritis, cardiovascular diseases, stroke, Graves' disease and intrahepatic cholestasis ${ }^{9-13}$. Because of these remarkable studies, it is claimed that MPV can be a promising and potential blood marker of inflammation. However, although serum MPV is found to be statistically different in control groups in most of the clinical trials, some results of the studies, particularly those investigating local inflammations such as Graves' disease, psoriasis and rheumatoid arthritis, are conflicting and unsatisfactory ${ }^{13-15}$.

Chronic gastric inflammation is an example of 1ocal chronic inflammation. $H$. pylori is one of the most important reasons for this. Hypothetically, every chronic tissue injury activates platelets, and MPV reflects this action well. The potential relationship between $H$. pylori and platelet count has been shown before. However, there are few and conflicting papers about the relationship between MPV and $H$. pylori related chronic gastric inflammation and its severity. There are only two studies in the field, and confusing results are presented as well. Topal et al. ${ }^{9}$ found that no statistically significant difference was obtained and there was no correlation and relationship between MPV and $H$. pylori intensity or gastric inflammation severity, whereas Umit and $\ddot{U}^{m i t}{ }^{16}$ report that the mean platelet count was lower in $H$. pylori positive patients than in $H$. pylori negative patients, whereas the mean MPV was higher in $H$. pylori positive group than in $H$. pylori negative group.

In this study, we aimed to evaluate the relationship between the mean MPV and gastric inflammation severity, being $H$. pylori positive or negative. With this study, we hope to make an important contribution to the literature by clarifying the topic that has been presented with controversial results so far.

\section{Material and Method}

This study was conducted at the Gastroenterology Department, Zonguldak Bülent Ecevit University Medical Faculty, a tertiary reference center for all endoscopic procedures. A total of 6890 endoscopic reports and case files from January 2013 to June 2017 were reviewed meticulously. The main criteria for inclusion in the study were as follows: dyspeptic patients aged 18-85 who had no cancer history and gastric surgery in the past; patients with upper gastrointestinal endoscopy and at least four biopsies taken from the antrum and corpus or small curvature of stomach; patients with gastric biopsy specimens stained with hematoxylin-eosin and assessed in accordance with Sydney classification; and patients that had complete blood count within the normal range before upper endoscopy and standard ferritin, iron, and C-reactive protein (CRP) levels. The main exclusion criteria were as follows: patients with gastric or colon dysplasia or polyps and any malignancy; patients with acute phase responses such as high level of CRP and ferritin and leukocytosis; patients with any chronic disease such as chronic hepatitis $\mathrm{B}$ or $\mathrm{C}$, cirrhosis, rheumatologic diseases; patients with any hematologic disease; patients with malabsorption syndrome; and patients using special medication that could change platelet count. All laboratory blood tests were accepted if they were taken before upper endoscopy by international guidelines. Histopathological reports were accepted if the investigation was made according to Sydney classification. $H$. pylori infection and other parameters were recorded as the degree of intensification and severity as none, mild $(+)$, moderate $(++)$ and severe $(+++)$. This study was conducted in accordance with the International Helsinki Declaration. The local ethics committee approved this work (code 2017-07-13). A written informed consent was obtained from all patients having participated in the study. 
Table 1. Basic study demography

\begin{tabular}{|l|l|l|l|}
\hline & $\begin{array}{l}\text { H.pylori } \\
(+)\end{array}$ & $\begin{array}{l}\text { H. pylori } \\
(-)\end{array}$ & $\mathrm{p}$ \\
\hline Patients (n, \%) & $118(54.2 \%)$ & $100(45.8 \%)$ & 0.799 \\
Age (yrs) & $52.8 \pm 13.6$ & $52.3 \pm 15.5$ & 0.724 \\
Gender (male/female) & $64 / 54$ & $55 / 45$ & 0.910 \\
Platelet x106 $\mu / \mathrm{mL}$ (NR: $140-400)$ & $250 \pm 58.8$ & $243 \pm 49.7$ & 0.724 \\
MPV (fL) (NR:7-10.5) & $8.67 \pm 1.02$ & $8.68 \pm 0,81$ & 0.998 \\
Hemoglobin (mg/dL) (NR: 12-16.5) & $14.1 \pm 1.23$ & $14.2 \pm 1.15$ & 0.495 \\
MCV (fL) (NR:80-99) & $87.2 \pm 3.31$ & $87.7 \pm 3.79$ & 0.330 \\
Ferritin (mg/dL) (NR:11-308.6) & $46.2(9.5-253)$ & $43.2(11-323)$ & 0.903 \\
Serum iron ( $\mu$ g/dL) (NR: 60-180) & $77 \pm 27.9$ & $76,62 \pm 30.07$ & 0.923 \\
CRP (mg/dL) (NR: 0-8) & $2.54 \pm 1.46$ & $3.06 \pm 1.12$ & 0.854 \\
Endoscopic findings: & & & \\
ESG & 45 & 69 & $\mathrm{NS}$ \\
lower esophageal sphincter dysfunction + ESG & 65 & 56 & \\
ESG + ulcer or erosion of bulbs & 8 & 5 & \\
\hline
\end{tabular}

H. pylori $=$ Helicobacter pylori $\mathrm{NR}=$ normal range; $\mathrm{NS}=$ nonsignificant; $\mathrm{MPV}=$ mean platelet volume; $\mathrm{MCV}=$ mean corpuscular volume; $\mathrm{CRP}=\mathrm{C}$-reactive protein; ESG = erythematous superficial gastritis; MPV was not different between $H$. pylori positive and $H$. pylori negative groups $(\mathrm{p}>0.05)$.

\section{Statistical analysis}

On statistical analysis, the Windows compatible SPSS 18 (Chicago, Illinois, USA) program was used. First, it was searched whether all data distributions were normal or not with at least three tests including Kolmogorov Smirnov test; then appropriate statistical methods were selected. Normally distributed data were presented as mean \pm standard deviation, whereas the data without normal distribution were introduced as median with minimum-maximum levels. The Mann Whitney $U$, one way ANOVA, independent samples test, Student's T-test and $\chi^{2}$-test were used to compare data groups. The level of statistical significance was set at $\mathrm{p}<0.05$.

\section{Results}

A total of 218 patients were enrolled in this study. The main evaluation was initiated by dividing the group into $H$. pylori positive and $H$. pylori negative patients. There were $118(54.2 \%) H$. pylori positive and $100(45.8 \%) H$. pylori negative patients. Age, gender, hemoglobin, mean corpuscular volume, ferritin, CRP, serum iron, endoscopic findings, and platelet count were similar in both groups ( $p>0.05$ all) (Table 1$)$. The MPV and platelet count did not differ between $H$. pylori positive and $H$. pylori negative groups ( $\mathrm{p}>0.05)$. There was no difference in the mean MPV levels between the subgroups of inflammation according to Sydney classification ( $p>0.05$ all). There was no correlation between the mean MPV levels and the severity of inflammation either (Table 2). When evaluating the mean $\mathrm{MPV}$ as $<9.15 \mathrm{fL}$ and $>9.15 \mathrm{fL}$ with gender matching (according to the study by Icli et al. ${ }^{12}$ ), there were no differences between $H$. pylori positive and $H$. pylori negative groups either ( $p>0.05$ all) (Table 3 ).

\section{Discussion}

In this study, we evaluated the relationship between the mean MPV and chronic gastric inflammation severity, with $H$. pylori positive and negative. Our main findings showed that the mean MPV was not different between $H$. pylori positive and $H$. pylori negative groups ( $p>0.05$ ), and no statistical correlation and differences were found among the gastric inflammation subgroups, or in the severity of inflammation according to Sydney classification. We analyzed MPV measurement by stratifying $<9.15 \mathrm{fL}$ and $>9.15 \mathrm{fL}$ groups, 
but we found no differences between $H$. pylori positive and $H$. pylori negative groups. The most powerful parts of our work were as follows: we analyzed all patient files very carefully and selected the cases among special

Table 2. Mean platelet volume (MPV) values were not different among inflammation groups, so there was no correlation between $M P V$ and severity of gastric inflammation ( $p>0.05$ all)

\begin{tabular}{|l|l|l|}
\hline $\begin{array}{l}\text { Sydney } \\
\text { classification (n) }\end{array}$ & $\begin{array}{l}\text { Mean platelet volume (fL) } \\
(\text { mean } \pm \text { standard deviation) }\end{array}$ & $\mathrm{p}$ \\
\hline $\begin{array}{l}\text { Helicobacter pylori } \\
\text { (n): }\end{array}$ & $\mathrm{NS}$ \\
$\quad$ none (100) & $8.68 \pm 0.81$ & \\
mild (75) & $8.75 \pm 0.99$ & \\
modarate (29) & $8.46 \pm 1.06$ & \\
severe (14) & $8.71 \pm 1.1$ & $\mathrm{NS}$ \\
Inflammation (n): & & \\
none (3) & $8.46 \pm 0.72$ & \\
mild (54) & $8.6 \pm 0.84$ & \\
moderate (104) & $8.71 \pm 0.92$ & $\mathrm{NS}$ \\
severe (57) & $8.69 \pm 1.04$ & \\
Activation (n): & $8.66 \pm 0.9$ & \\
none (131) & $8.67 \pm 0.94$ & \\
mild (44) & $8.69 \pm 1.04$ & \\
moderate (39) & $9.3 \pm 0.51$ & $\mathrm{NS}$ \\
severe (3) & & \\
Intestinal & & \\
metaplasia (n): & & \\
none (166) & $8.67 \pm 0.94$ & \\
mild (42) & $8.65 \pm 0.88$ & \\
moderate (10) & $8.85 \pm 0.99$ & \\
severe (0) & 0 & \\
Atrophy (n): & $8.67 \pm 0.89$ & \\
none (190) & $8.71 \pm 1.18$ & \\
existing (28) & & \\
\hline
\end{tabular}

NS = nonsignificant patient groups who had no serious chronic disease except for dyspepsia, and therefore we kept such patients out of the study if it was the smallest factor that could affect the results such as a drug, chronic inflammatory disease, etc.; unlike previous studies, we measured CRP levels in all patients to exclude any acute or chronic inflammation that could affect platelet function. Therefore, even a patient with the smallest CRP elevation was not included in the study; and all endoscopic procedures and histologic examinations were done by the same clinicians having at least ten years of experience in the field. So, the diagnosis of $H$. pylori and gastric inflammation scores were very reliable. The most important limitation of our work was its retrospective design.

Our results were similar to the study by Topal et al. ${ }^{9}$, but different from the study by Umit and $\ddot{U} \mathrm{mit}^{16}$. In the former involving 114 patients, there was no correlation or difference between the mean MPV and $H$. pylori presence, as well as gastric inflammation severity ( $p>0.05)$. Our study had a higher number of patients than the study by Topal et al. ${ }^{9}$ (218 vs. 114), so our results could be more reliable than those reported by these authors. Moreover, they did not consider all factors that might affect MPV and platelet function in their study; unlike them, we did take in consideration important $\mathrm{pa}^{-}$ rameters such as $\mathrm{CRP}$ and iron storage status. The study by Umit and Ümit ${ }^{16}$ that included 4823 patients found the mean MPV and platelet count to be statistically different between $H$. pylori positive and $H$. pylori negative groups $(\mathrm{p}<0.001)$. They also report that $20.5 \%$ of $H$. pylori positive patients had a higher MPV value ( $>10 \mathrm{fL})$, while $2.8 \%$ of $H$. pylori negative patients had high MPV $(>10 \mathrm{fL})$, and this finding was statistically significant $(\mathrm{p}<0.001)$. These results are completely different from the results of our study and the study by Topal et al. ${ }^{9}$. Therefore, we considered this result as conflicting and

Table 3. MPV evaluation as $<9.15 \mathrm{fL}$ and $>9.15 \mathrm{fL}$ with gender-matched subjects (according to the study by Icli et al. ${ }^{12}$ ) yielded no statistical difference between $H$. pylori positive and negative groups ( $\left.p>0.05\right)$

\begin{tabular}{|c|c|c|c|c|c|c|}
\hline & \multicolumn{2}{|l|}{ Female $(\mathrm{n}=99)$} & \multirow[b]{2}{*}{$\mathrm{p}$} & \multicolumn{2}{|l|}{ Male $(n=119)$} & \multirow[b]{2}{*}{$\mathrm{p}$} \\
\hline & $\begin{array}{l}\text { MPV(fL) } \\
<9.15(\mathrm{n}=72)\end{array}$ & $\begin{array}{l}\text { MPV(fL) } \\
>9.15 \\
(\mathrm{n}=27)\end{array}$ & & $\begin{array}{l}\operatorname{MPV}(\mathrm{fL}) \\
<9.15(\mathrm{n}=82)\end{array}$ & $\begin{array}{l}\text { MPV(fL) } \\
>9.15 \\
(\mathrm{n}=37)\end{array}$ & \\
\hline H. pylori (+) & \multirow{2}{*}{$\begin{array}{l}38(52.8 \%) \\
34(47.2 \%)\end{array}$} & \multirow{2}{*}{$\begin{array}{l}16(56.3 \%) \\
11(40.7 \%)\end{array}$} & \multirow{2}{*}{0.726} & $40(48.8 \%)$ & $24(64.9 \%)$ & \multirow{2}{*}{0.153} \\
\hline H. pylori (-) & & & & $42(51.2 \%)$ & $13(35.1 \%)$ & \\
\hline Total (218\%100) & 72 (100\%) & 27 (100\%) & & 82 (100\%) & 37 (100\%) & \\
\hline
\end{tabular}

H. pylori $=$ Helicobacter pylori $\mathrm{MPV}=$ mean platelet volume; $\mathrm{fL}=$ femtolitre 
Table 4. Summary of studies investigating the relationship between MPV and H. pylori related gastric inflammation severity

\begin{tabular}{|l|l|l|l|l|l|l|l|}
\hline Author & $\begin{array}{l}\text { Patients (n) } \\
(\mathrm{f} / \mathrm{m})\end{array}$ & Year & $\begin{array}{l}\text { Age (yrs) } \\
(\text { mean) }\end{array}$ & $\begin{array}{l}\text { MPV(fL) } \\
(\mathrm{mean})\end{array}$ & $\mathrm{Plt}$ & $\mathrm{p}$ & Result/Conclusion \\
\hline Topal et al. & $\begin{array}{l}114 \\
(73 / 41\end{array}$ & 2010 & $38.5 \pm 13.12$ & $8.8 \pm 1.4$ & - & $>0.05$ & $\begin{array}{l}\text { MPV level cannot be used as a } \\
\text { simple marker to reflect } \text { H. pylori } \\
\text { intensity and severity of } \\
\text { inflammation }\end{array}$ \\
\hline $\begin{array}{l}\text { Umit } \\
\text { and Ümit }\end{array}$ & $\begin{array}{l}4823 \\
(2233 / 2600)\end{array}$ & 2015 & $60(18-80)$ & $8.79 \pm 1$ & $247 \pm 82$ & $<0.001$ & $\begin{array}{l}\text { Higher MPV values were observed } \\
\text { in H. pylori positive patients }\end{array}$ \\
\hline Güçlü et al. ${ }^{21}$ & $\begin{array}{l}199 \\
(111 / 88)\end{array}$ & 2017 & $46.5 \pm 14$ & $10.1 \pm 0.7$ & $270 \pm 79$ & $>0.05$ & $\begin{array}{l}\text { There were no differences between } \\
\text { MPV and total } H \text {. pylori-negative } \\
\text { patients and } \text { H. pylori positive } \\
\text { patients }\end{array}$ \\
\hline $\begin{array}{l}\text { Akar } \\
\text { present } \\
\text { study) }\end{array}$ & $\begin{array}{l}218 \\
(99 / 119)\end{array}$ & 2018 & $52.8 \pm 13.6$ & $8.67 \pm 1.02$ & $250 \pm 58$ & $>0.05$ & $\begin{array}{l}\text { There were no differences in mean } \\
\text { MPV between } \text { H. pylori positive } \\
\text { and negative patients or among } \\
\text { chronic gastric inflammation } \\
\text { subgroups }\end{array}$ \\
\hline
\end{tabular}

H. pylori $=$ Helicobacter pylori $\mathrm{MPV}=$ mean platelet volume; $\mathrm{fL}=$ femtolitre; $\mathrm{Plt}=$ platelet $\mathrm{f}=$ female; $\mathrm{m}=$ male

Topal et al. ${ }^{9}$ found that there was no relationship between mean MPV and chronic gastric inflammation severity being $H$. pylori positive or negative, whereas Umit and Ümit ${ }^{16}$ claimed that higher MPV values were observed in $H$. pylori positive patients

discordant information due to some reasons. In their study, Umit and Ümit ${ }^{16}$ included 4823 patients who had undergone upper endoscopy, but no endoscopic findings are reported. According to that study, it is doubtful how the $H$. pylori diagnosis was obtained. Another problem associated with that study was that it was carried out between 2004 and 2014 (ten years), so this long working time could have caused data loss or changes, thus the data could not be homogeneous. Consequently, we did not find the results reported by Umit and Ümit ${ }^{16}$ as reliable. In Table 4, we summarized the studies of MPV and $H$. pylori presence, as well as gastric inflammation severity.

The MPV has recently become a favorite topic of many researchers as a simple, easy-going and inexpensive marker of chronic inflammation-related diseases ${ }^{14,17,18}$. In many studies involving systemic diseases such as diabetes mellitus or Behçet disease, the mean MPV was statistically different between patient group and control group ${ }^{19,20}$. However, this difference was not shown in localized inflammatory diseases such as Graves' disease or rheumatoid arthritis ${ }^{13,15}$.

Up to now, H. pylori is still a hot topic, and it continues to be the subject of many studies. Nowadays, MPV has been presented as a new, promising and straightforward marker of inflammation. However, there are only a few studies demonstrating a relationship between MPV and $H$. pylori. Conflicting results have been presented so far. These studies are briefly summarized in Table 4 with essential demographic data and results/conclusions. Our study is the fourth paper evaluating MPV and gastric inflammation severity, being $H$. pylori positive or negative. Our work contributes to the literature by clarifying this issue, which has a small number of contradictory information, as clearly seen in the literature summary. To us, when the inflammation is located at a highly limited site such stomach and anterior part of the eye, there is not enough cytokine and immunomodulator release, thus platelet activation from bone marrow is not so prominent to activate $\mathrm{MPV}^{8}$.

In conclusion, although MPV has recently emerged as a marker of inflammation in many systemic diseases, there is still an ongoing debate about its diagnostic usefulness and benefit in daily clinical practice. This paper is the fourth study to investigate the relationship between MPV and H. pylori related chronic gastric inflammation severity. Our results show that MPV is not a useful marker of chronic gastric inflammation severity, being $H$. pylori positive or negative. 


\section{References}

1. Díaz P, Valenzuela Valderrama M, Bravo J, Quest AFG. Helicobacter pylori and gastric cancer: adaptive cellular mechanisms involved in disease progression. Front Microbiol. 2018;9:5.

2. Dutta AK, Reddy VD, Iyer VH, Unnikrishnan LS, Chacko A. Exploring current status of Helicobacter pylori infection in different age groups of patients with dyspepsia. Indian J Gastroenterol. 2017 Nov;36(6):509-513. doi: 10.1007/s12664-0170810-0. Epub 2018 Jan 24.

3. Muhammad JS, Zaidi SF, Saeed SA, Ishaq M. Current status of Helicobacter pylori association with haematological and cardiovascular diseases: a mini review. J Pak Med Assoc. 2017;67(6):907-11.

4. Yun ZY, Li N, Zhang X, et al. Mean platelet volume, platelet distribution width and carcinoembryonic antigen to discriminate gastric cancer from gastric ulcer. Oncotarget. 2017;8(37):62600-5.

5. Shichijo S, Nomura S, Aoyama K, et al. Application of convolutional neural networks in the diagnosis of Helicobacter pylori infection based on endoscopic images. EBioMedicine. 2017;25:106-11.

6. Moayyedi PM, Lacy BE, Andrews CN, Enns RA, Howden CW, Vakil N. ACG and CAG Clinical Guideline: Management of Dyspepsia. Am J Gastroenterol. 2017;112(7):9881013.

7. Shetty V, Ballal M, Balaraju G, Shetty S, Pai GC, Lingadakai R. Helicobacter pylori in dyspepsia: phenotypic and genotypic methods of diagnosis. J Glob Infect Dis. 2017;9(4):131-4.

8. Noris P, Melazzini F, Balduini CL. New roles for mean platelet volume measurement in the clinical practice? Platelets. 2016;27(7):607-12.

9. Topal F, Karaman K, Akbulut S, et al. The relationship between mean platelet volume levels and the inflammation in Helicobacter pylori gastritis. J Natl Med Assoc. 2010;102(8):726-30.

10. Bahali AG, Su O, Emiroglu N, Cengiz FP, Kaya MO, Onsun $\mathrm{N}$. Evaluation of mean platelet volume in localized scleroderma. An Bras Dermatol. 2017;92(5):635-7.
11. Kılıç S, Reşorlu H, Işik S, et al. Association between mean platelet volume and disease severity in patients with psoriasis and psoriatic arthritis. Postepy Dermatol Alergol. 2017;34(2):126-30.

12. Icli A, Aksoy F, Turker Y, et al. Relationship between mean platelet volume and pulmonary embolism in patients with deep vein thrombosis. Heart Lung Circ. 2015;24(11):1081-6.

13. Bagir GS, Haydardedeoglu FE, Bakiner OS, Bozkirli E, Ertorer ME. Mean platelet volume in Graves' disease: a sign of hypermetabolism rather than autoimmunity? Pak J Med Sci. 2017;33(4):871-5.

14. Avci A, Avci D, Erden F, et al. Can we use the neutrophil-tolymphocyte ratio, platelet-to-lymphocyte ratio, and mean platelet volume values for the diagnosis of anterior uveitis in patients with Behcet's disease? Ther Clin Risk Manag. 2017;13:881-6.

15. Moghimi J, Ghahremanfard F, Salari M, Ghorbani R. Association between mean platelet volume and severity of rheumatoid arthritis. Pan Afr Med J. 2017;27:276.

16. Umit H, Ümit EG. Helicobacter pylori and mean platelet volume: a relation way before immune thrombocytopenia? Eur Rev Med Pharmacol Sci. 2015;19(15):2818-23.

17. Chen X, Fang L, Lin H, et al. The relationship between type 2 diabetes and platelet indicators. Iran J Public Health. 2017;46(9):1211-6.

18. Lei JJ, Zhou L, Liu Q, Xiong C, Xu CF. Can mean platelet volume play a role in evaluating the severity of acute pancreatitis? World J Gastroenterol. 2017;23(13):2404-13.

19. Yayla Abide Ç, Vural F, Kılıççı Ç, et al. Can we predict severity of intrahepatic cholestasis of pregnancy using inflammatory markers? Turk J Obstet Gynecol. 2017;14(3):160-5.

20. Uslu AU, Aydin B, Balta S, Yonem O, Uncu T, Seven D. The effect of standard therapy on mean platelet volume in patients with chronic hepatitis C. Prz Gastroenterol. 2016;11(3):200-5.

21. Guclu M, Agan F. Association of severity of Helicobacter pylori infection with peripheral blood neutrophil to lymphocyte ratio and mean platelet volume. Euroasian J Hepatogastroenterol. 2017 Jan-Jun;7(1):11-6. 


\title{
Sažetak \\ MOŽE LI VOLUMEN TROMBOCITA UKAZIVATI \\ NA POZITIVAN STATUS NA HELICOBACTER I TEŽINU UPALE ŽELUCA? IZVORNO ISTRAŽIVANJE I PREGLED LITERATURE
}

\begin{abstract}
T. Akar
Helicobacter pylori (H.pylori) je čest problem i značajan uzrok kronične upale želuca. H. pylori, trajna upala želuca i njezina težina su najkritičnija komponenta prekursora raka želuca. Hipotetski, svaka kronična ozljeda tkiva aktivira trombocite, a srednji volumen trombocita (mean platelet volume, MPV) dobro odražava njihovo djelovanje. Potencijalni odnos između $H$. pylori i broja trombocita je prikazan ranije. Međutim, postoji i nekoliko suprotnih članaka o odnosu između MPV i kroničnih upala želuca povezanih s $H$. pylori i njihove težine. Istraživanje je imalo za cilj procjenjivati bilo koji potencijalni odnos između MPV i postojanja $H$. pylori, kao i težine kronične upale želuca. U početku je evaluirano 6890 endoskopskih izvješća, a uključeno je ukupno 218 dispeptičnih bolesnika koji su podvrgnuti gornjoj endoskopiji. Od njih je 118 (54,2\%) bolesnika bilo pozitivno na $H$. pylori, dok ih je $100(45,8 \%)$ bilo negativno na $H$. pylori. Najmanje četiri želučane biopsije su uzete i ocjenjivane prema klasifikaciji Sydney. Zabilježeni su i dob, spol, hemoglobin, srednji korpuskularni volumen, feritin, serumsko željezo i C-reaktivni protein te endoskopski nalazi. Vrijednost $\mathrm{p}<0,05$ je prihvaćena kao značajna. MPV i broj trombocita nisu se razlikovali između skupina bolesnika pozitivnih i negativnih na $H$. pylori $(p>0,05)$. Također nije bilo razlike $\mathrm{i}$ korelacije između MPV i težine upale želuca prema klasifikaciji Sydney (p>0,05). Kada je MPV stratificiran kao $<9,15 \mathrm{fL}$ i $>9,15 \mathrm{fL}$, također nije nađena nikakva razlika između skupina bolesnika pozitivnih i negativnih na $H$. pylori (p>0,05). U ovom istraživanju nismo pronašli nikakav odnos između MPV i postojanja $H$. pylori, kao i težine upale želuca. Iako u ovom pogledu još postoje sukobljene publikacije, za nas i ovu studiju MPV nije prikladan biljeg za procjenu jačine želučanih upala, bez obzira je li H. pylori pozitivan ili negativan.
\end{abstract}

Ključne riječi: Srednji volumen trombocita; Helicobacter pylori; Gastritis; Upala 